Proceedings

\title{
Influence of Color Temperature of White LED Diodes and Illumination Intensity on the Content of Photosynthetic Pigments in Chlorella vulgaris Algae Cells ${ }^{\dagger}$
}

\author{
Paweł Kondzior ${ }^{1, *}$, Damian Tyniecki ${ }^{2}$ and Andrzej Butarewicz ${ }^{1}$ \\ 1 Department of Chemistry, Biology and Biotechnology, Bialystok University of Technology, 15-351 \\ Bialystok, Poland \\ 2 Department of Electrical Power Engineering, Bialystok University of Technology, 15-351 Bialystok, Poland \\ * Correspondence: p.kondzior@doktoranci.pb.edu.pl; Tel.: +48-85-746-96-59 \\ + Presented at Innovations-Sustainability-Modernity-Openness Conference (ISMO'19), Bialystok, Poland, \\ 22-23 May 2019.
}

Published: 18 July 2019

\begin{abstract}
The purpose of this paper is to determine the influence of color temperature of Light Emitting Diode (LED) diodes and illumination intensity on the content of photosynthetic pigments of chlorophyll a, chlorophyll b and carotenoids in Chlorella vulgaris algae cells. Choosing the right color temperature and intensity of illumination can favorably affect the growth of algae. In particular, it can contribute to the efficiency of the photosynthesis process and the amount of produced biomass from Chlorella vulgaris algae. In the spectrophotometric studies, the highest content of chlorophyll a, chlorophyll $\mathrm{b}$ and carotenoids was found in cultures illuminated with very cold white light $(8500 \mathrm{~K})$ with an intensity of $500 \mu \mathrm{mol} / \mathrm{m}^{2} \mathrm{~s}$. The highest measured content of chlorophyll a (Chl a) pigments was $48.29 \mathrm{mg} / \mathrm{L}$, Chl b pigment was $23.25 \mathrm{mg} / \mathrm{L}$ and carotenoids pigment was $12.65 \mathrm{mg} / \mathrm{L}$; the smallest content of pigments for Chl a $(11.48 \mathrm{mg} / \mathrm{L}), \mathrm{Chl} \mathrm{b}(4.69 \mathrm{mg} / \mathrm{L})$ and carotenoids $(3.03 \mathrm{mg} / \mathrm{L})$ was found in the sample illuminated with warm white light $(3200 \mathrm{~K})$ with an intensity of $50 \mu \mathrm{mol} / \mathrm{m}^{2} \mathrm{~s}$. The highest amount of dry organic matter amounting to $2.0 \mathrm{~g} / \mathrm{L}$ was found in a sample illuminated with warm white light $(3200 \mathrm{~K})$ with an intensity of 250 $\mu \mathrm{mol} / \mathrm{m}^{2} \mathrm{~s}$, then $1.91 \mathrm{~g}$ dry organic mass (DOM)/L for very cold white light with an intensity of 250 $\mu \mathrm{mol} / \mathrm{m}^{2} \mathrm{~s}$, and $1.48 \mathrm{~g} \mathrm{DOM} / \mathrm{L}$ for very cold white light with an intensity of $50 \mu \mathrm{mol} / \mathrm{m}^{2} \mathrm{~s}$. The obtained results show that a higher content of photosynthetic pigments does not directly affect the increase of the amount of dry organic matter.
\end{abstract}

Keywords: photosynthetic pigments; algae; Chlorella vulgaris; LED diodes; illumination

\section{Introduction}

The purpose of this paper is to determine the influence of the color temperature of Light Emitting Diode (LED) diodes and illumination intensity on the content of photosynthetic pigments of chlorophyll $\mathrm{a}$, chlorophyll $\mathrm{b}$ and carotenoids in Chlorella vulgaris algae cells. The photosynthetic pigments transform the energy of light into the energy of chemical bonds, from which algae synthesize organic compounds (saccharides) in the process of photosynthesis from simple inorganic compounds. Choosing the right color temperature and intensity of illumination can favorably affect the growth of algae. In particular, it can contribute to the efficiency of the photosynthesis process and the amount of produced biomass from Chlorella vulgaris algae. 


\section{Material and Methods}

Chlorella vulgaris algae from the University of Bialystok were used in the study. BG-11 Medium for Blue Green Algae ATCC Medium 616 was used to grow algae. The volume of culture medium was $500 \mathrm{~cm}^{3}$, the incubation temperature was $25^{\circ} \mathrm{C}$, and continuous lighting was provided. LED panels based on 84 diodes (Surface Mounted Device (SMD) 5630) were used for lighting. The influence of warm white $(3200 \mathrm{~K})$, cold white $(6500 \mathrm{~K})$ and very cold white $(8500 \mathrm{~K})$ was studied. Each color of lighting was tested at three intensity levels: $500 \mu \mathrm{mol} / \mathrm{m}^{2} \mathrm{~s}, 250 \mu \mathrm{mol} / \mathrm{m}^{2} \mathrm{~s}$ and $50 \mu \mathrm{mol} / \mathrm{m}^{2} \mathrm{~s}$. The intensity of illumination was measured with the Delta OHM HD 2102.1 photoradiometer with the LP 471 Photosynthetically Active Radiation (PAR) sensor. The color temperature measurement was measured using the GL SPECTIS 1.0 Touch GLX10 tf spectrometer. The pigment content was measured spectrophotometrically with a Hach Lange DR 5000 on day 2, day 4, day 6, day 9 and day 15 of incubation. For this purpose, a $5 \mathrm{~cm}^{3}$ culture was taken as a test sample. The test sample was centrifuged at 4500 Revolutions Per Minute (RPM) for 10 minutes using the MPW-352R centrifuge. The supernatant was decanted and $5 \mathrm{~cm}^{3}$ of $90 \%$ methanol was added to the centrifuged mass of the algae. Then, the test-tubes were closed with a bacteriological stopper and then mixed and placed in a steam bath set at $60^{\circ} \mathrm{C}$ for $10 \mathrm{~min}$. After this, the sample was centrifuged again for $10 \mathrm{~min}$ at 4500 RPM and the resulting supernatant was subjected to spectrophotometric analysis at wavelengths of $470 \mathrm{~nm}, 652 \mathrm{~nm}$ and $665 \mathrm{~nm}$. The pigment content was calculated from the formulas published in Xiong et al. [1]:

$$
\begin{aligned}
\text { Chlorophyll } a & =16.82 A_{665}-9.28 A_{652}\left[\frac{\mathrm{mg}}{\mathrm{L}}\right], \\
\text { Chlorophyll } b & =36.92 A_{652}-16.54 A_{665}\left[\frac{\mathrm{mg}}{\mathrm{L}}\right], \\
C_{\text {carotenoid }} & =\frac{\left(1000 A_{470}-1.91 C_{a}-95.15 C_{b}\right)}{225}\left[\frac{\mathrm{mg}}{\mathrm{L}}\right],
\end{aligned}
$$

\section{Results and Discussion}

\subsection{Characteristics of LED Panels}

LED panels have been measured in terms of the emitted spectrum. The graphs depicting the emitted spectrum by the LEDs are shown in Figure 1. The spectra emitted by the sun are also shown for comparison. The color temperature of the panels was also tested, and the result was obtained: the measured value of warm white $(3200 \mathrm{~K})$ was $3015 \mathrm{~K}$, the measured value of cold white $(6500 \mathrm{~K})$ was $6845 \mathrm{~K}$, and the measured value of very cold white $(8500 \mathrm{~K})$ was $15,290 \mathrm{~K}$. The results of the color temperature tests show similarity with the data provided by the manufacturer with the exception of very cold white $(8500 \mathrm{~K})$, where the discrepancy is high and the value is almost twice as high. 


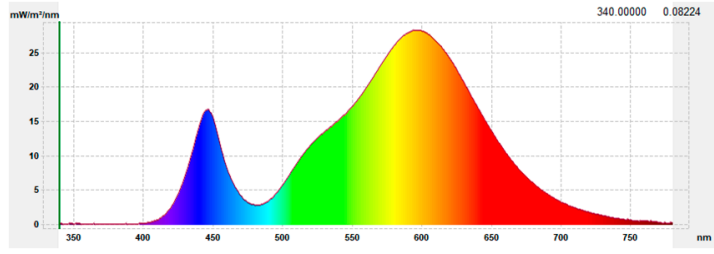

(a)

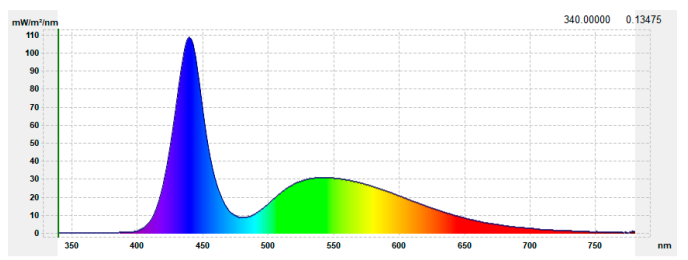

(c)

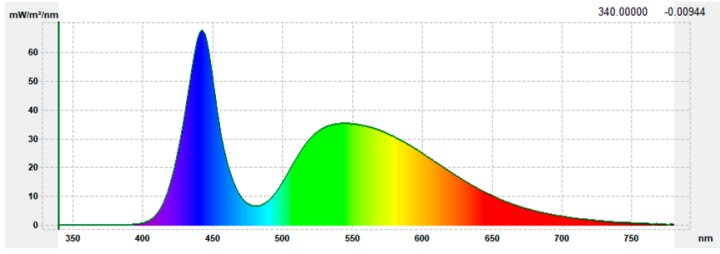

(b)

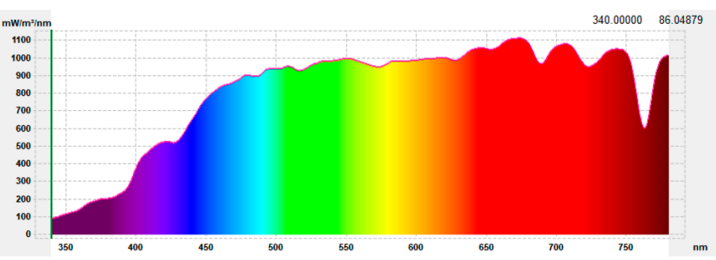

(d)

Figure 1. Spectrum emitted by Light Emitting Diode (LED) diodes and the sun: (a) warm white (3200 $\mathrm{K})$; (b) cold white $(6500 \mathrm{~K})$; (c) very cold white ( $8500 \mathrm{~K})$; (d) the sun (in the range of $350 \mathrm{~nm}$ to $800 \mathrm{~nm}$ ).

\subsection{The Content of Pigments and Cultured Algae Biomass}

On the day 15 of incubation, the grown biomass from Chlorella vulgaris was analyzed. In the spectrophotometric studies, the highest content of chlorophyll a, chlorophyll b and carotenoids was found in cultures illuminated with very cold white light $(8500 \mathrm{~K})$ with an intensity of $500 \mu \mathrm{mol} / \mathrm{m}^{2} \mathrm{~s}$. The highest measured content of pigments was $48.29 \mathrm{mg} / \mathrm{L}$ for Chl a, $23.25 \mathrm{mg} / \mathrm{L}$ for Chl b and 12.65 $\mathrm{mg} / \mathrm{L}$ for carotenoids. The smallest content of pigments $(11.48 \mathrm{mg} / \mathrm{L}$ for $\mathrm{Chl} \mathrm{a}, 4.69 \mathrm{mg} / \mathrm{L}$ for $\mathrm{Chl} \mathrm{b}$, and $3.03 \mathrm{mg} / \mathrm{L}$ for carotenoids) was found in the sample illuminated with warm white light (3200 K) with an intensity of $50 \mu \mathrm{mol} / \mathrm{m}^{2} \mathrm{~s}$. The remaining results are shown in Table 1 . The highest amount of dry organic matter (DOM) amounting to $2.0 \mathrm{~g} / \mathrm{L}$ was found in a sample illuminated with warm white light $(3200 \mathrm{~K})$ with an intensity of $250 \mu \mathrm{mol} / \mathrm{m}^{2} \mathrm{~s}$, then $1.91 \mathrm{~g} \mathrm{DOM} / \mathrm{L}$ for very cold white light with an intensity of $250 \mu \mathrm{mol} / \mathrm{m}^{2} \mathrm{~s}$, and $1.48 \mathrm{~g} \mathrm{DOM} / \mathrm{L}$ for very cold white light with an intensity of 50 $\mu \mathrm{mol} / \mathrm{m}^{2} \mathrm{~s}$. The obtained results show that a higher content of photosynthetic pigments does not directly affect an increase in the amount of dry organic matter. When cultivating algae to produce biomass, it is more reasonable to choose the illuminating intensity of $250 \mu \mathrm{mol} / \mathrm{m}^{2} \mathrm{~s}$. This will contribute to increasing the amount of biomass (expressed as DOM) for warm white light (3200 K) by $171 \%$, cold white by $147 \%$ and very cold white by $205 \%$.

An important role in collecting excess energy is played by carotenoids, especially zeaxanthin. The zeaxanthin pigment is synthesized during strong illumination in the xanthophyll cycle, while during a lack of illumination, the pigment passes through the antheraxanthin in the process of epoxidation into violaxanthin. Therefore, the appearance of zeaxanthin can indirectly inform about the saturation of the photosynthesis process, and directly about the excess of light energy [2]. 
Table 1. Results of testing the content of photosynthetic pigments and the amount of cultured biomass from Chlorella vulgaris algae on day 15 of incubation.

\begin{tabular}{|c|c|c|c|c|c|c|c|c|c|c|}
\hline \multirow{2}{*}{ Color Temperature } & \multirow{2}{*}{$\begin{array}{l}\text { Intensity of } \\
\text { Illumination }\end{array}$} & \multicolumn{3}{|c|}{$\begin{array}{c}\text { The Content of Photosynthetic } \\
\text { Pigments }\end{array}$} & \multirow{2}{*}{$\begin{array}{l}\text { Dry } \\
\text { Mass }\end{array}$} & \multirow{2}{*}{$\begin{array}{l}\text { Dry Organic Mass } \\
\text { (DOM) }\end{array}$} & \multirow{2}{*}{$\begin{array}{l}\text { Dry Mineral } \\
\text { Mass }\end{array}$} & \multirow{2}{*}{$\begin{array}{c}\mathrm{Chl} \\
\mathrm{a} / \mathrm{DOM}\end{array}$} & \multirow{2}{*}{$\begin{array}{c}\text { Chl } \\
\text { b/DOM }\end{array}$} & \multirow{2}{*}{$\begin{array}{l}\text { Carotenoid } \\
\quad \text { /DOM }\end{array}$} \\
\hline & & $\begin{array}{c}\text { Chlorophyll a } \\
\text { (Chl a) }\end{array}$ & Chl b & Carotenoids & & & & & & \\
\hline Unit & $\left(\mu \mathrm{mol} / \mathrm{m}^{2} \mathrm{~s}\right)$ & $(\mathrm{mg} / \mathrm{L})$ & $(\mathrm{mg} / \mathrm{L})$ & $(\mathrm{mg} / \mathrm{L})$ & $(\mathrm{g} / \mathrm{L})$ & $(\mathrm{g} / \mathrm{L})$ & $(\mathrm{g} / \mathrm{L})$ & $(\%)$ & $(\%)$ & $(\%)$ \\
\hline \multirow{3}{*}{ Warm white (3200 K) } & 500 & 42.92 & 22.69 & 11.42 & 1.84 & 1.17 & 0.67 & 36.68 & 19.40 & 9.76 \\
\hline & 250 & 38.69 & 18.09 & 10.29 & 2.63 & 2.00 & 0.63 & 19.35 & 9.05 & 5.14 \\
\hline & 50 & 11.48 & 4.69 & 3.03 & 1.87 & 1.41 & 0.46 & 8.14 & 3.33 & 2.15 \\
\hline \multirow{3}{*}{$\begin{array}{c}\text { Cold } \\
\text { white }(6500 \mathrm{~K})\end{array}$} & 500 & 16.42 & 7.48 & 4.99 & 1.22 & 0.75 & 0.47 & 21.89 & 9.98 & 6.65 \\
\hline & 250 & 30.33 & 14.09 & 8.43 & 1.77 & 1.10 & 0.67 & 27.57 & 12.81 & 7.66 \\
\hline & 50 & 14.18 & 6.07 & 3.78 & 1.93 & 1.30 & 0.63 & 10.90 & 4.67 & 2.91 \\
\hline Very & 500 & 48.29 & 23.25 & 12.65 & 1.43 & 0.93 & 0.50 & 51.92 & 25.00 & 13.60 \\
\hline cold & 250 & 40.46 & 17.89 & 10.85 & 2.41 & 1.91 & 0.50 & 21.18 & 9.37 & 5.68 \\
\hline white $(8500 \mathrm{~K})$ & 50 & 17.31 & 7.72 & 4.59 & 2.04 & 1.48 & 0.56 & 11.69 & 5.21 & 3.10 \\
\hline
\end{tabular}




\section{Conclusions}

The obtained results show that a higher content of photosynthetic pigments does not directly affect an increase of the amount of dry organic matter. The increased amount of photosynthetic pigment in samples illuminated with the intensity of $500 \mu \mathrm{mol} / \mathrm{m}^{2} \mathrm{~s}$ (except the cold white color of $6500 \mathrm{~K})$ may be caused by the defenses of the Chlorella vulgaris algae cells. In order to better understand the processes occurring in the Chlorella vulgaris algae cells, future research should extend to determination of content photosynthetic pigments from the xanthophyll cycle.

Author Contributions: P.K. and A.B. conceived and designed the experiments; P.K. performed the biological research and analyzed the data under the supervision of A.B.; D.T. performed the lighting tests and analyzed the data under the supervision of A.B.; P.K., D.T. and A.B. contributed reagents materials and analysis tools; P.K., D.T. they wrote the paper under the supervision and review of A.B.

Acknowledgments: Studies have been carried out in the framework of the own work No. MB/WBiIŚ/5/2017 and funded by the Polish Ministry of Science and Higher Education.

Conflicts of Interest: The authors declare no conflict of interest.

\section{References}

1. Xiong, J.Q.; Kurade, M.B.; Abou-Shanab, R.A.I.; Ji, M.K.; Choi, J.; Kim, J.O.; Jeon, B.H. Biodegradation of Carbamazepine Using Freshwater Microalgae Chlamydomonas Mexicana and Scenedesmus Obliquus and the Determination of Its Metabolic Fate. Bioresour. Technol. 2016, 205, 183-190, doi:10.1016/j.biortech.2016.01.038.

2. Gabryś, H.; Kacperska-Lewak, A.; Kopcewicz, J.; Krzymowska, M.; Lewak, S.; Rychter, A.; Starck, Z.; Strzałka, K.; Szymańska, M.; Tretyn, A.; et al. Plant Physiology (In Polish); Polish Scientific Publishers PWN: Warsaw, Poland, 2012.

(C) 2019 by the authors. Licensee MDPI, Basel, Switzerland. This article is an open access article distributed under the terms and conditions of the Creative Commons Attribution (CC BY) license (http://creativecommons.org/licenses/by/4.0/). 